\title{
In-vitro and in-vivo anti-inflammatory activity of Andrographis serpyllifolia (Rottl. Ex Vahl.) Wt.
}

\author{
Vasu Kandati1,2, P Govardhan ${ }^{3}$, Ch Siva Reddy ${ }^{4}$, A Ravinder Nath 5 , *R R Reddy ${ }^{2}$ \\ ${ }^{1}$ Faculty of Pharmaceutical Sciences, JNTU, Hyderabad, Andhra Pradesh, India \\ ${ }^{2}$ Arya College of Pharmacy, Kandi-502285, Sanga Reddy, Andhra Pradesh, India \\ ${ }^{3}$ Department of Pharmacology, Vaagdevi College of Pharmacy, Warangal-506001, Andhra Pradesh, India \\ ${ }^{4}$ Department of Pharmacology, KVSR Siddhartha College of Pharmaceutical Sciences, Vijayawada-520010, Andhra Pradesh, India \\ ${ }^{5}$ Department of Pharmacy, Osmania Universtiy, Hyderabad-500007, Andhra Pradesh, India
}

\begin{abstract}
The study was aimed to evaluate the analgesic and anti-inflammatory activity (by both in-vitro and in-vivo) of both chloroform and methanol root extracts of Andrographis serpyllifolia (Rottl. Ex Vahl.) Wt. Methods used for the studies were In-vitro 5-Lipoxygenase inhibition assay and In-vivo measurement of rat paw edema and ear edema in rats, acetic acid induced writhing response and hot plate method in albino mice. Chloroform and methanolic extracts of $A$. serpyllifolia root have shown moderate potency in inhibiting 5-LOX and shown significant anti-inflammatory activity. Despite the IC $\mathrm{C}_{0}$ values are little higher, anti-inflammatory efficacy of these extracts possibly due to other mechanisms apart of 5-LOX inhibition. However, In-vivo anti-inflammatory studies revealed that $A$. serpyllifolia methanolic extract has shown higher degree of efficacy when compared to the chloroform extract. In terms of analgesic activity in writhing test, methanolic extract has shown more efficacy than chloroform extract. Hence, it is important to isolate the active principles for further testing the anti-inflammatory efficacy.
\end{abstract}

Key Words: Andrographis serpyllifolia, anti-inflammatory, analgesic, 5-LOX, In-vivo animal models.

\section{INTRODUCTION}

Tirumala Hills (Rayalaseema region, Andhra Pradesh, India), which lie geographically in the South Eastern Ghats are well-known for the rich heritage of flora. Andrographis serpyllifolia (Rottl. Ex Vahl.) Wt. (Acanthaceae) is a trailing and rooting procumbent herb widely distributed throughout South India. All the parts of A. serpyllifolia are important in the traditional system of medicine in India which has been extensively used for snake bites, antipyretics, cancer and inflammation (Sekhar et al., 2011). The root extract of the plant is used to cure fever (Ramaswamy et al., 1973). The plant extract is used in treating wounds and also effective

\footnotetext{
*Corresponding Author:

Dr. R. Raja Reddy, M. Pharm, Ph. D

Professor and Principal

Arya College of Pharmacy, Kandi-502285

Sanga Reddy Mandal, Medak District

Andhra Pradesh, India

E-mail: rajareddyr1962@gmail.com

Contact No.: +919490318793
}

in the treatment of Jaundice (Manjunatha et al., 2004). But still there is no specific study on $A$. serpyllifolia for its analgesic and anti-inflammatory activity. Hence, in the present study, chloroform and methanol extracts of roots of A. Serpyllifolia was investigated for analgesic and anti-inflammatory activity in vitro and in vivo in animal models.

\section{MATERIALS AND METHODS}

\section{Collection of plant material}

Roots of Andrographis serpyllifolia (Rottl. Ex Vahl.) Wt. were collected from surrounding areas of Tirupati and Tirumala hills, was identified and authenticated by the botanist Dr. K. Madhava Chetty, Assistant Professor, Department of Botany, S. V. University, Tirupati. A voucher specimen (Herbarium Accession No. 136) was deposited in the herbarium, Department of Botany, S.V. University, Tirupati. 
Table 1: Experimental designs for various in-vivo animal models of inflammation.

\begin{tabular}{|c|c|c|c|}
\hline Groups & $\begin{array}{l}\text { Experimental design } \\
\text { (Rat paw edema) }\end{array}$ & $\begin{array}{l}\text { Experimental design } \\
\text { (Writhing test/Hot plate) }\end{array}$ & $\begin{array}{l}\text { Experimental design } \\
\text { (Ear edema test in mice) }\end{array}$ \\
\hline Group 1 & Control Group & Control Group & Control Group (0.5 mg/ear) \\
\hline Group 2 & Diclofenac $40 \mathrm{mg} / \mathrm{kg}$, p.o. & Diclofenac $40 \mathrm{mg} / \mathrm{kg}$, p.o. & ASC-0.5 mg/ear \\
\hline Group 3 & ASC-100 mg/kg,p.o. & ASC-100 mg/kg,p.o. & ASM-0.5 mg/ear \\
\hline Group 4 & ASC-200 mg/kg,p.o. & ASC-200 mg/kg,p.o. & Diclofenac Sodium (0.5 mg/ear) \\
\hline Group 5 & ASM-100 mg/kg, p.o. & ASM-100 mg/kg, p.o. & \\
\hline Group 6 & ASM-200 mg/kg,p.o. & ASM-200 mg/kg,p.o. & \\
\hline
\end{tabular}

\section{Preparation of Plant Extracts and Phytochemical Screening}

The fresh roots $(2 \mathrm{Kg})$ of Andrographis serpyllifolia subjected for air dried and powdered. The root powder was extracted successively with petroleum ether, chloroform and methanol using soxhlet apparatus. All the extracts were filtered using cotton plug followed by Whatman filter paper. The extracts were concentrated using rotary vaccum evaporator (Buchi USA) and then dried in lyophilizer (Labconco USA) under reduced pressure. The dried extracts were stored in airtight container and placed in refrigerator. The root extracts of A. serpyllifolia were analyzed for the presence of flavonoids, alkaloids, glycosides, steroids, phenols, saponins, terpenoid, cardiac glycosides and tannins according to the standard methods (Harborne et al., 1973; Mondal and Suresh, 2012).

\section{Animals}

Wistar rats weighing 150-200 g and Albino mice 20$30 \mathrm{~g}$ of either sex (National Institute of Nutrition (NIN), Hyderabad, India) was used for in-vivo pharmacological studies. Animals were maintained under standard laboratory conditions at $25 \pm 2^{\circ} \mathrm{C}$, $50 \pm 15 \% \mathrm{RH}$ and normal photoperiod (12h dark / 12h light). Commercial pellet diet (NIN) and water were provided ad libitum. The experimental protocol was approved by the Institutional Animal Ethics Committee of Vaagdevi College of Pharmacy, Hanamkonda, Warangal, Andhra Pradesh, India and by the Animal Regulatory Body of the Government of India (Regd. No. 1047/ac/07/CPCSEA). The experimental designs for various in-vivo models of inflammation were tabulated in table 1.

\section{Acute Toxicity}

Acute oral toxicity study was performed as per OECD-423 guidelines (acute toxic class method).
Albino mice $(n=6)$ of either sex selected by random sampling technique were used for the study. The animals were kept fasting for overnight providing only water, after which the extracts were administered orally at the dose level of $5 \mathrm{mg} / \mathrm{kg}$ body weight by oral feeding needle and observed for 14 days. Mortality was not observed, the procedure was repeated for further higher dose such as 50, 300, $2000 \mathrm{mg} / \mathrm{kg}$ body weight (Ecobichon, 1997).

\section{In-vitro 5-Lipoxygenase Inhibition}

The assay mixture contained $80 \mathrm{mM}$ linoleic acid and sufficient amount of potato 5-lipooxygenase enzyme in 50mM phosphate buffer ( $\mathrm{pH}-6.3$ ) and incubate for 2 minutes for reaction. The reaction was initiated by the addition of enzyme buffer mixture to substrate (linoleic acid) and the enzyme activity was monitored as in increase in absorbance at $234 \mathrm{~nm}$ using UV kinetic mode on (Agilent technologies-Varian Cary-50) UV-visible spectrophotometer. In the inhibition studies, the activities were measured by incubating various concentration of test substance with enzyme buffer mixture for 2 minutes before addition of the substrate. The assay was performed in triplicate and mean values were used for the calculation. Percentage inhibition was calculated by comparing slope or increase in absorbance of the test substance with that of control enzyme activity. The activity of 5-LOX was compared with the standard positive control, Zileutin (Reddenna et al., 1990; Ulusu et al., 2002).

\section{Acetic Acid-induced Writhing Test}

Albino mice, weighing 20-30 g, were randomly divided into groups $(\mathrm{n}=6)$, acetic acid was administered intraperitonialy to the experimental animals to create pain sensation. The extracts were solubilized in the ratios of (1:1) propylene glycol one drop and starch suspension. The plant extract, $A$. serpyllifolia 
Table 2: Phytochemical screening of A. serpyllifolia methanolic and chloroform extracts.

\begin{tabular}{lcc}
\hline $\begin{array}{l}\text { Photochemical } \\
\text { Constituents }\end{array}$ & Methanolic extract & $\begin{array}{c}\text { Chloroform } \\
\text { extract }\end{array}$ \\
\hline Flavonoids & + & + \\
Alkaloids & + & + \\
Glycosides & + & + \\
Steroids & + & + \\
Phenols & + & + \\
Terpenoid & + & + \\
Saponins & + & + \\
Resins & - & - \\
Tannins & + & + \\
Cardiac Glycosides & + & + \\
\hline- =absent, + =present & &
\end{tabular}

in two different doses $(100 \mathrm{mg} / \mathrm{kg}$ and $200 \mathrm{mg} / \mathrm{kg}$, b.w) and vehicle were administered orally 30 minutes prior to intraperitoneal administration of $1 \% \mathrm{v} / \mathrm{v}$ acetic acid solution $(0.1 \mathrm{~mL} / 10 \mathrm{~g})$ but diclofenac sodium was administered 15 minutes prior to acetic acid injection. Then the animals were placed on an observation table. Each mouse from all groups were observed individually for counting the number of writhing they made in 15 minutes commencing just 5 minutes after the intraperitoneal administration of acetic acid solution. Full writhing was not always accomplished by the animal, because sometimes the animals started to give writhing but they did not complete it. This incomplete writhing was considered as half-writhing. Accordingly, two half-writhing were taken as one full writhing. The number of writhes in each treated group was compared to that of a control group while diclofenac sodium $(40 \mathrm{mg} / \mathrm{kg})$ was used as a reference substance positive control.

\section{Measurement of Paw Edema}

Edema was induced by injecting $0.1 \mathrm{~mL}$ of $1 \%$ solution of carragenan in saline to (sub plantar) right hind paw of rats. The plant extract, A. serpyllifolia in two different doses $(100 \mathrm{mg} / \mathrm{kg}$ and 200 $\mathrm{mg} / \mathrm{kg}, \mathrm{b} . \mathrm{w})$ and vehicle were administered orally 60 minutes prior to injection of carragenan. The volume of edema of injected and contra collateral paws were measured at $0.5,1,1.5,2,3,4,5$ hours after induction of inflammation using a plethysmograph and the percentage of anti-inflammatory activity was calculated.

\section{TPA Induced Ear Edema}

Each mouse received $2.5 \mu \mathrm{g}$ of TPA (12-Otetradecanoylphorbol-13-acetate) dissolved in $20 \mu \mathrm{L}$ of $70 \% \mathrm{EtOH}$. This was applied by an automatic pipette in $20 \mu \mathrm{L}$ volumes to both anterior and posterior surfaces of the right ear. The left ear (control) received the same volume of solvent (EtOH 70\%), simultaneously with TPA. Diclofenac sodium $(0.5 \mathrm{mg} /$ ear) was used as a standard drug. The thickness of each ear was measured $4 \mathrm{~h}$ after induction of inflammation using a gauge calipers. The edema was expressed as the difference between right and left ears due to TPA application.

\section{Hot Plate Method}

Albino mice of either sex were selected, weighed and divided into six groups $(n=6)$. The time of reaction to pain stimulus of the mice placed on the plate, heated at $55^{\circ} \pm 0.5^{\circ} \mathrm{C}$ was recorded at $1,2,3,4$ and $5 \mathrm{hrs}$, after the administration of the plant extracts, A. serpyllifolia in two different doses $(100 \mathrm{mg} / \mathrm{kg}$ and $200 \mathrm{mg} / \mathrm{kg}$, b.w) and vehicle were administered orally before 60 minutes. The increase in reaction time against control group was calculated.

\section{Statistical Analysis}

Values from in-vivo anti-inflammatory and analgesic activity shown in tables and figures were Mean \pm SD for six animals. Analysis was performed using oneway analysis of variance (ANOVA) and Tukey's post hoc multiple comparison tests (by "GraphPad Prism 5" software) was applied for determining the statistical significance between different groups. The results were significant in the level of ${ }^{*} \mathrm{p}<0.05$, ${ }^{* *} \mathrm{p}<0.01 \&{ }^{* * *} \mathrm{p}<0.001$.

\section{RESULTS}

\section{Phytochemical Screening}

In the methanolic and chloroform extracts of $A$. serpyllifolia, flavanoid, alkaloid and phenols were present. Glycosides, saponins, tannins and cardiac glycosides are also present. Resins are absent (Table 2).

\section{Acute Toxilogical Studies}

To establish the safety of the extracts (methanolic and chloroform) administered to both male and female mice. We observed no significant toxic signs or death during the 14 days observation period. None of the mice showed clinical toxic signs such as 
Table 3: In-vitro 5-LOX inhibition of Andrographis serpyllifolia extracts.

\begin{tabular}{ll}
\hline Plant extract $($ A. serpyllifolia) & IC $_{50}(\mu \mathrm{g} / \mathrm{ml})$ \\
\hline Methanolic root extract & 42.14 \\
Chloroform root extract & 107.72 \\
Petroleum ether root extract & 180.06 \\
Zileutin & 4.36 \\
\hline
\end{tabular}

anorexia, depression, lethargy, jaundice, dermatitis and also, no mortality happened throughout the examination. The plant extracts did not exhibit any mortality up to the dose level of $2000 \mathrm{mg} / \mathrm{kg}$. So, the extracts were safe for long term administration. The results were found that there is no testicular toxicity for $1000 \mathrm{mg} / \mathrm{kg}$ of Andrographis paniculata (Burgos et al., 1987), hence the dose of the extracts were up to $1000 \mathrm{mg} / \mathrm{kg}$ was safe.

\section{In-vitro 5-LOX inhibition}

The $\mathrm{IC}_{50}$ values of petroleum ether, chloroform and methanolic extracts of $A$. serpyllifolia and standard drug, zileutin against 5-LOX inhibition were found to be $180.06 \mu \mathrm{g} / \mathrm{mL}, 107 \mu \mathrm{g} / \mathrm{mL}, 42.14 \mu \mathrm{g} / \mathrm{mL}$, and $4.36 \mu \mathrm{g} / \mathrm{mL}$ respectively (Table 3 ). The 5-LOX inhibition activity of $A$. serpyllifolia extracts were not reported and published by other workers till date.

\section{Effect Plant Extracts on Rat Paw Edema}

Carrageenan-induced edema is a biphasic response. The first phase is mediated through the release of histamine, serotonin and kinins where as, the second phase is related to the release of prostaglandin and slow reacting substances which peak at $3 \mathrm{~h}$.

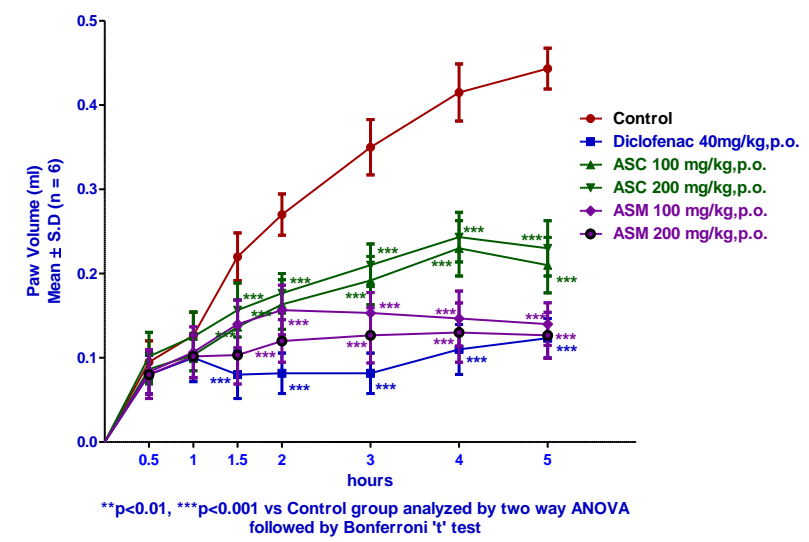

Figure 1: Effect of both A. serpyllifolia methanolic root extract (ASM) chloroform root extract (ASC) and on rat paw edema of wistar rats.
Table 4: Effects of both A. serpyllifolia methanolic root extract (ASM) and chloroform root extract (ASC) against TPA-induced ear edema in mice as measurement of swelling thickness.

\begin{tabular}{lll}
\hline Test Groups & $\begin{array}{l}\text { Dose } \\
(\mathbf{m g} / \mathbf{e a r})\end{array}$ & $\begin{array}{l}\text { Swelling thickness } \\
(\mu \mathrm{m}) \pm \text { S.E.M }\end{array}$ \\
\hline $\begin{array}{l}\text { Control Group } \\
\begin{array}{l}\text { A. serpyllifolia methanolic } \\
\text { extract (ASM) }\end{array}\end{array}$ & 0.5 & $262.34 \pm 21.8$ \\
$\begin{array}{l}\text { A. serpyllifolia chloroform } \\
\text { extract (ASC) }\end{array}$ & 0.5 & $120.25 \pm 16.2^{* * *}$ \\
Diclofenac Sodium & 0.5 & $22.35 \pm 0.5^{* * *}$ \\
\hline
\end{tabular}

The chloroform and methanol extracts of A. serpyllifolia root at the dose level of $100 \mathrm{mg} / \mathrm{kg}$ and $200 \mathrm{mg} / \mathrm{kg}$ decreased the oedema significantly $(\mathrm{p}$ $<0.001)$ at $3^{\text {rd }}$ and $4^{\text {th }}$ hour after administration. When compared to the control group, the effect was almost comparable with standard drug diclofenac sodium at $3^{\text {rd }}$ and $4^{\text {th }}$ hour after administration (Figure 1). Methanolic extract of A. serpyllifolia root has exhibited more degree of anti-inflammatory activity than chloroform extract.

\section{Effect of Plant Extracts on Mouse Ear Edema}

Similar pattern of activity was followed for both the measurements of ear swelling thickness. Both chloroform and methanolic root extracts of $A$. serpyllifolia were shown significant antiinflammatory effect in mouse ear models. The swelling thickness of chloroform extract $(500 \mu \mathrm{g})$, methanolic extract $(500 \mu \mathrm{g})$ and control was shown as $120.25 \mu \mathrm{m}, 155.80 \mu \mathrm{m}$ and $262.34 \mu \mathrm{m}$ respectively. This result revealed that the methanolic extract

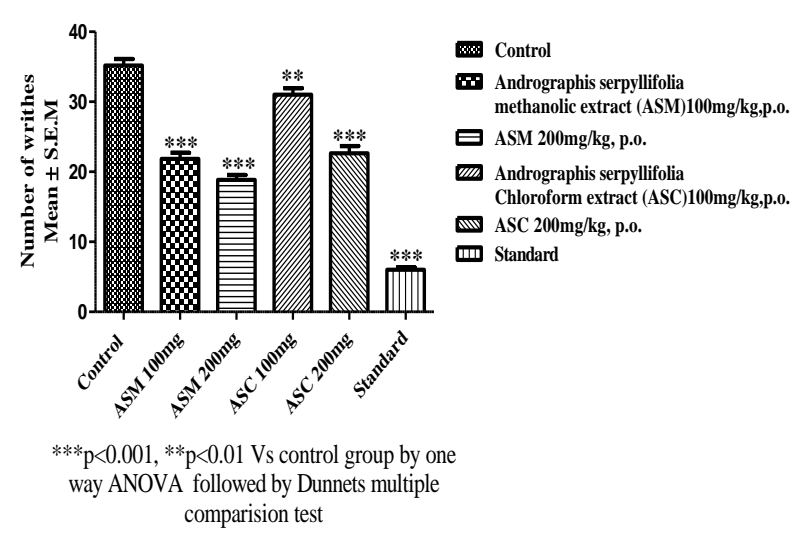

Figure 2: Effect of both $A$. serpyllifolia methanolic root extract (ASM) and chloroform root extract (ASC) on acetic acid induced writhes in albino mice. 
exhibited more degree of anti-inflammatory activity than chloroform extract (Table 4).

\section{Effect of plant extracts on acetic acid induced writhes}

The number of writhings was more in the chloroform extract with various doses of 100 and $200 \mathrm{mg} / \mathrm{kg}$ than methanolic extract with the same doses. This is clearly indicated that both chloroform and methanolic root extracts of $A$. serpyllifolia were shown significant reduction in the number of writhes, but methanolic extract exhibited more degree of anti-inflammatory activity than methanolic extract (Figure 2).

\section{Effect of plant extracts on Hot plate induced algesia} Standard drug, Tramadol $10 \mathrm{mg} / \mathrm{kg}$, p.o. has shown significant analgesic activity at the intervals of $1 \mathrm{~h}$ $\left({ }^{*} \mathrm{p}<0.05\right), 2 \mathrm{~h}\left({ }^{* * *} \mathrm{p}<0.001\right)$ and $3 \mathrm{~h}\left({ }^{* * *} \mathrm{p}<0.001\right)$ where as chloroform and methanolic extracts of Andrographis serpyllifolia have not shown any significant analgesic activity at two dose levels of $100 \mathrm{mg} / \mathrm{kg}$ and $200 \mathrm{mg} / \mathrm{kg}$ in mice, data tabulated in the Table 5 .

\section{DISCUSSION}

A. serpyllifolia methanolic extract might possess potent active principles which inhibits 5-LOX enzyme. IC50 values of methanolic and chloroform root extracts of A. serpyllifolia were found to be $42.14 \mu \mathrm{g} / \mathrm{mL}$ and $180.06 \mu \mathrm{g} / \mathrm{mL}$ respectively. It is apparent that these plant extracts are as potent as standard drug zileutin in inhibiting 5-LOX. However, potency of the drug always not necessarily reflects the efficacy of the drug. With this point of view, carried out in-vivo antiinflammatory and analgesic activity of $A$. serpyllifolia root extracts were performed.

The most widely used primary test to screen new anti-inflammatory agent's measure the ability of a compound to reduce local edema induced in the rat paw by injection of an irritant agent (Bonnie et al., 2005). Carrageenan induced oedema has been commonly used as an experimental animal model for acute inflammation and is believed to be biphasic. The early phase (1-2 h) of the carrageenan model is mainly mediated by histamine, serotonin and increased synthesis of prostaglandins in the damaged tissue surroundings. The late phase is sustained by prostaglandin release and mediated by bradykinin, leukotrienes, polymorphonuclear cells and prostaglandins produced by tissue macrophages (Winter et al., 1962). The similar trend was shown by methanolic extract of Euphorbia heyneana Spreng. (Ganga Rao et al., 2011).

A. serpyllifolia methanolic root extract has shown more significant anti-infalmmatory effect in two inflammatory models (carragenan induced paw edema and TPA induced ear edema) than chloroform root extract. Most important finding in this study is strong correlation between in-vitro and invivo anti-inflammatory data. Though potency of 5LOX inhibitory activity of this A. serpyllifolia root extracts was found to be low and anti-inflammatory efficacy of these plant extracts was found to be high and moreover, effect was dose dependent. This evidence heightened the importance of this plant extract for further evaluations to isolate the active principles that are contributing to the observed antiinflammatory activity.

Studies are under progress in our laboratory to isolate the compounds and to study the biological activities of the same. However, it is speculated that the probable mechanism of anti-inflammatory action of $A$. serpyllifolia may be due to its influence

Table 5: Effects of both A. serpyllifolia methanolic root extract (ASM) and chloroform root extract (ASC) on analgesia produced by hot plate method in mice.

\begin{tabular}{lccccc}
\hline \multirow{2}{*}{ Name of the Group } & \multicolumn{5}{c}{ Reaction time (Sec) } \\
\cline { 2 - 6 } & $\mathbf{1} \mathbf{~ h r}$ & $\mathbf{2 ~ h r}$ & $\mathbf{3 ~ h r}$ & $\mathbf{4 h r}$ & $\mathbf{5 h r}$ \\
\hline Control group & $16.3 \pm 0.64$ & $17.2 \pm 0.98$ & $17.6 \pm 1.56$ & $16.2 \pm 1.22$ & $18.1 \pm 1.46$ \\
Diclofenac Sodium $(40 \mathrm{mg} / \mathrm{kg})$ & $19.54 \pm 0.5^{*}$ & $23.36 \pm 0.84^{* * *}$ & $24.5 \pm 0.96^{* * *}$ & $22.5 \pm 0.96^{* * *}$ & $20 . .5 \pm 1.26$ \\
ASC-100 mg/kg, p.o. & $16.16 \pm 1.71$ & $18.50 \pm 0.80$ & $17.12 \pm 1.24$ & $18.42 \pm 1.24$ & $18.63 \pm 0.85$ \\
ASC-200 mg/kg,p.o. & $17.91 \pm 1.02$ & $17.08 \pm 1.35$ & $18.25 \pm 1.85$ & $17.32 \pm 0.74$ & $18.74 \pm 1.57$ \\
ASM-100 mg/kg, p.o. & $17.85 \pm 1.52$ & $18.45 \pm 1.28$ & $19.12 \pm 2.84$ & $18.12 \pm 1.35$ & $19.82 \pm 0.95$ \\
ASM-200 mg/kg,p.o. & $18.84 \pm 1.34$ & $18.50 \pm 0.86$ & $17.07 \pm 1.29$ & $18.76 \pm 1.55$ & $17.41 \pm 1.37$ \\
\hline ASC
\end{tabular}

$\mathrm{ASC}=A$. serpyllifolia cholroform extract; $\quad \mathrm{ASM}=A$. serpyllifolia methanolic extract

Each value is Mean \pm S.E.M $(n=6),{ }^{*}$ Denotes significance difference when compared to control values at ${ }^{*} p<0.05,{ }^{* * *} p<0.001$. 
on the cycloxygenase pathway (George et al., 2010 a, $2010 \mathrm{~b}$ ) since it is interfering with prostaglandins biosynthesis as evidenced by the maximum antiinflammatory activity at the end of the third hour after the challenge with carageenan. A. serpyllifolia methanolic extract has shown more degree of analgesic activity than exhibited potent analgesic activity than chloroform extract at the dose levels of $100,200 \mathrm{mg} / \mathrm{kg}$ in acetic acid induced writhing test. The same results were reported on Trigonella foenum-graecum Linn. (Moli et al., 2011). But both extracts did not exhibit the analgesic activity in hot plate method. This clearly indicated that the plant extracts which are possibly act through the peripheral mechanisms (Richardson et al., 1998) but not via the central mechanisms. Extracts have demonstrated to have analgesic effect in acetic acid induced writhes. This result provides evidence that plant extracts might possess active principles which produce peripheral analgesic effect without mediating spinal and supra-spinal actions. At present, there are no reports on investigation to identify the active components present in methanolic extract of A. serpyllifolia.

\section{CONCLUSION}

Andrographis serpyllifolia methanolic root extract has shown moderate potency in the inhibition of 5-LOX. Methanolic root extract of $A$. serpyllifolia exhibited more degree of anti-inflammatory activity than chloroform extract in in-vitro studies. Methanolic extract of $A$. serpyllifolia exhibited more degree of analgesic activity than chloroform extract in in-vivo studies. Based on the correlation between both invitro data and in-vivo data, it was concluded that $A$. serpyllifolia methanolic root extract possibly consists of more anti-inflammatory active principles than chloroform extract. Further investigations are anticipated to identify the active components and lead to their further clinical use.

\section{DECLARATIONS}

Conflict of interest: The authors declare that they have no conflict of interest to disclose. Funding: This research received no specific grant from any funding agency in the public, commercial or not-for-profit sectors.

\section{ACKNOWLEDGEMENT}

We are grateful to the Department of Arya College of Pharmacy, Vaagdevi College of Pharmacy for providing research facilities for in-vivo pharmacological studies, Laila Impex Pharma Ltd for providing the research facilities for in-vitro studies in the present investigation.

\section{REFERENCES}

Battu GR, Ethadi SR, Veda Priya G, Swathi Priya K, Chandrika K, Venkateswara Rao A, Reddy S (2011) Evaluation of antioxidant and anti-inflammatory activity of Euphorbia heyneana Spreng, Asian Pacific Journal of Tropical Biomedicine, pages S191-S194.

Bonnie Sun Pan, Ying-Yu Kuo, Tsui-Yao Chen, Yeuk-Chuen Liu, (2005) Anti-oxidative and anti-inflammatory activities of two different species of a Chinese herb I-Tiao-Gung, Life Sciences, volume 77, pages 28302839. [DOI] PMid:15958273

Burgos RA, Caballero EE, Sanchez NS, Schroeder RA, Wikman GK, Hancke JL (1997) Instituto de Farmacologia, Facultad de Ciencias Veterinarias, Universidad Austral de Chile, Valdivia. Journal of Ethnopharmacology, volume 58, issue 3, pages 219-224. [DOI]

Ecobichon DJ (1997) The basis of toxicology testing. RC press, New York, pages $43-86$.

Georgewill OA, Georgewill UO (2010) Evaluation of the antiinflammatory activity of extract of Vernonia amygdalina. Asian Pacific Journal of Tropical Medicine, volume 3, issue 2, pages 150-151. [DOI]

Georgewill OA, Georgewill UO, Nwankwoala RNP (2010) Antiinflammatory effects of Morninga oleifera lam extract in rats. Asian Pacific Journal of Tropical Medicine, volume 3, issue 2, pages 133-135. [DOI]

Harborne JB (1973) Phytochemical methods, A Guide to Modern Techniques of plant analysis, Chapman and Hall, London, Ltd: pages 49-188.

Manjunatha BK, Krishna V, Pullaiah T. (2004) Flora of Davanagere district, Karnataka, India. Regency Publications, New Delhi, page 300.

Akter M, Afroze M, Khatun A (2011) Evaluation of analgesic, neuropharmacological and cytotoxic activity of Trigonella foenum-graecum Linn., International Current Pharmaceutical Journal, 1(1): 6-11. [DOI]

Mondal S, Suresh P (2012) Wound healing activity of Cleome rutidosperma DC. roots., International Current Pharmaceutical Journal, 1( 6): 151154. [DOI]

Ramaswamy SV, Razi BA (1973) Flora of Bangalore District. Prasaranga, University of Mysore, Mysore; page 565.

Reddenna P, Whelan J, Maddipati KR, Reddy (1990) Purification of arachidonate 5-LOX from potato tubers. Methods in Enzymology, volume 187, pages 268-277. [DOI]

Richardson JD, Aanonsen L, Hargreaves KM and et al., (1998) Antihyperalgesic effects of spinal cannabinoids. European Journal of Pharmacology, volume 345, pages 145-153. [DOI]

Sekhar J, Penchala pratap G, Sudarsanam G, Prasad GP (2011) Ethnic information on treatments for snake bites in Kadapa district of Andhra Pradesh, Life sciences Leaflets, 12: 368 -375.

Ulusu NN, Ercil D, Sakar MK, Tezcan EE (2002) Abietic acid inhibits lipooxygenase activity, Phytotherapeutics Research, volume 16, pages 88-90. [DOI] PMid:11807975

Winter CA, Risley EA, Nuss W (1962) Carrageenan induced edema in hind paw of rats as an assay for anti-inflammatory drugs. Process Society Experimental Biological Medicine, volume 111, pages 544-547. PMid:14001233 